\title{
A NEW GOLD-COLORED LEPANTHES (PLEUROTHALLIDINAE: ORCHIDACEAE) FROM SOUTHEAST ECUADOR
}

\author{
Luis E. Baquero ${ }^{1,4}$, Javier J. Donoso T. ${ }^{2}$ \& Marco M. JiméneZ ${ }^{3}$ \\ ${ }^{1}$ Grupo de Investigación en Medio Ambiente y Salud BIOMAS, Carrera de Ingeniería Agroindustrial \\ y Alimentos, Facultad de Ingeniería y Ciencias Agropecuarias, Universidad de Las Américas, \\ Calle José Queri, Quito 170137, Pichincha, Ecuador \\ ${ }^{2}$ Instituto Nacional de Biodiversidad, Quito, Ecuador \\ ${ }^{3}$ Avenida del Ejército y Juan Izquierdo, Zamora, Ecuador \\ ${ }^{4}$ Corresponding author: lbaquero@hotmail.com
}

\begin{abstract}
Lepanthes vere-aurum, a new species of the orchid subtribe Pleurothallidinae, discovered in Zamora Chinchipe province, southeast Ecuador, is described here. We compare L. vere-aurum to L. brenneri, the only similar species, from which it differs in having larger leaves and longer inflorescences. Also, $L$. vere-aurum has an obovate, concave, long-acuminate dorsal sepal and a concave appendix with a pubescent crest underneath and with a long, pubescent apex,versus a flat, triangular-ovate, acuminate dorsal sepal and a smaller appendix with a ciliate apex in L. brenneri. Some information about its phenology and ecology is additionally provided.

Resumen. Lepanthes vere-aurum, una nueva especie de orquídea de la subtribu Pleurothallidinae, fue descubierta en la provincia de Zamora Chinchipe, sureste de Ecuador, y es descrita aquí. Lepanthes vereaurum es comparada con $L$. brenneri, la única especie similar, de la que se diferencia por plantas con hojas más grandes e inflorescencias más largas. Además, L. vere-aurum posee un sépalo dorsal obovado, cóncavo y largamente acuminado y un apéndice cóncavo con una cresta pubescente por debajo y el ápice largo y pubescente, versus el sépalo dorsal plano triangular-ovado y acuminado y, un apéndice más pequeño y ciliado en L. brenneri. Se presenta información sobre la fenología y ecología de la especie.
\end{abstract}

Key Words / Palabras clave: Cordillera del Cóndor, endangered orchid, Epidendroideae, Lepanthes brenneri, nueva especie, new orchid species, orquídea amenazada

Introduction. Ecuador is rich in orchid diversity, with around 4187 species, of which 1706 are endemic (Endara \& Jost 2012). In Zamora Chinchipe province (southeast Ecuador) alone, 221 orchid species are endemic, which represents $13 \%$ of the endemic orchids of the country (Endara \& Jost 2012). This might be explained, in part, by peculiar geological characteristics that produce several ecosystems with different elevations and temperatures (Jiménez V. \& Jiménez L. 2014).

Lepanthes $\mathrm{Sw}$. is one of the mega-diverse genera of Pleurothallidinae orchids with more than 1100 species. In Ecuador, more than 300 species of Lepanthes are known (Luer 1996, Thoerle \& Hirtz 2015, Karremans 2016, Baquero 2018, Baquero et al. 2018, Tobar et al. 2018, Baquero et al. 2019, Zambrano \& Solano 2019). The species of Lepanthes have ramicauls enclosed by lepanthiform sheaths, flowers with transversely expanded petals with two or three lobes, a complex lip (with some exceptions) with a body connecting a pair of blades which normally embrace the column, and a very small structure at the base of the lip which has been called the "appendix" (Luer 1996). The appendix is present in species which are believed to be pollinated by small gnats via pseudocopulation, where the male insects confuse the structures with the female genitalia and pollinate the orchids during the attempt to copulate (Blanco \& Barboza 2005). A new species from southeast Ecuador has been recently discovered and it is described here.

\section{TAXONOMIC TREATMENT}

Lepanthes vere-aurum Donoso \& Baquero, sp. nov. (Fig. 1-2). 


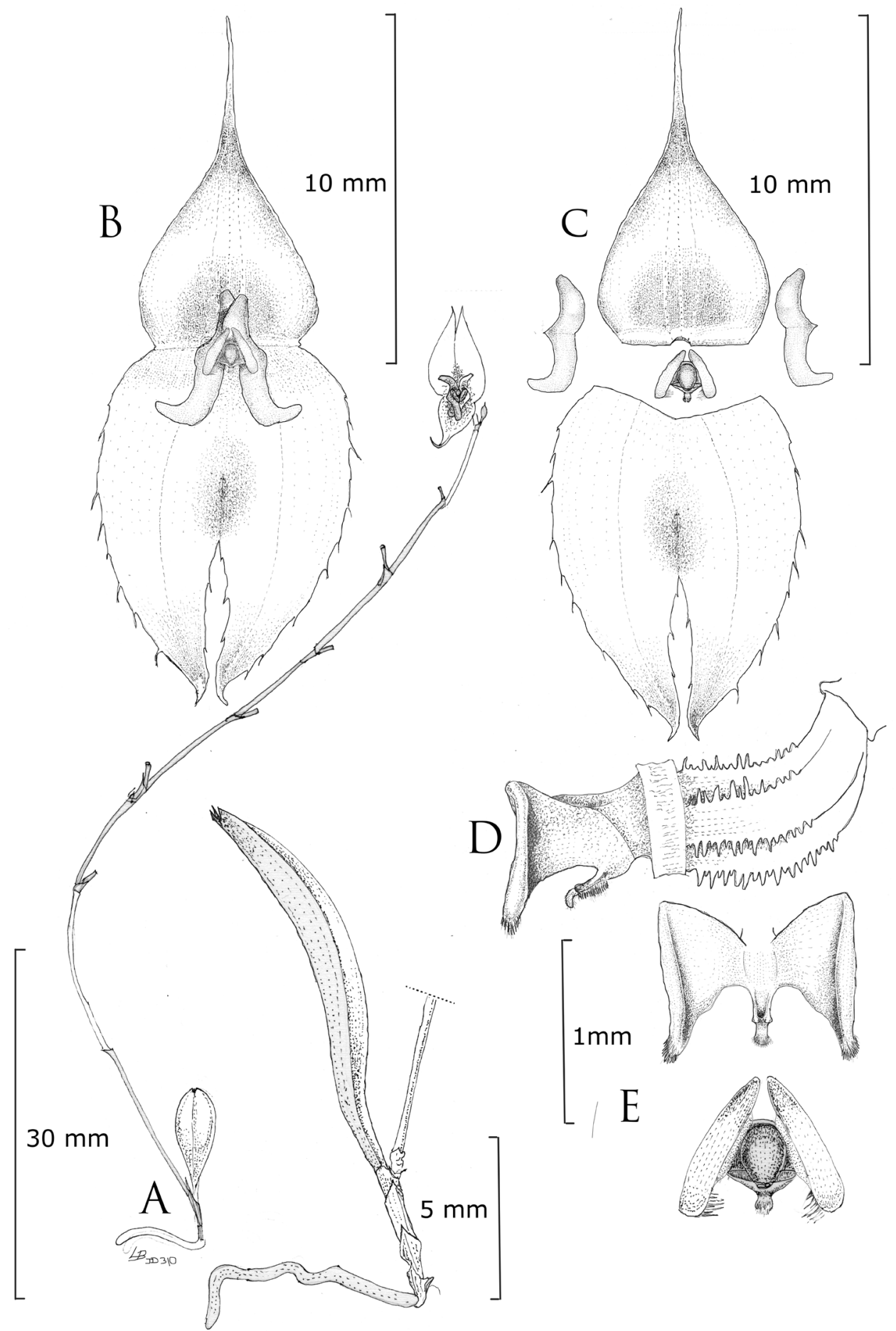

Figure 1. Lepanthes vere-aurum Donoso \& Baquero. A. Habit and plant close-up. B. Flower, frontal view. C. Dissected perianth. D. Lateral view of the lip and ovary. E. Adaxial view of the expanded lip and frontal view of the lip, appendix and column. Illustration by Luis Baquero, based on the holotype Javier Donoso \#310 (QCNE). 

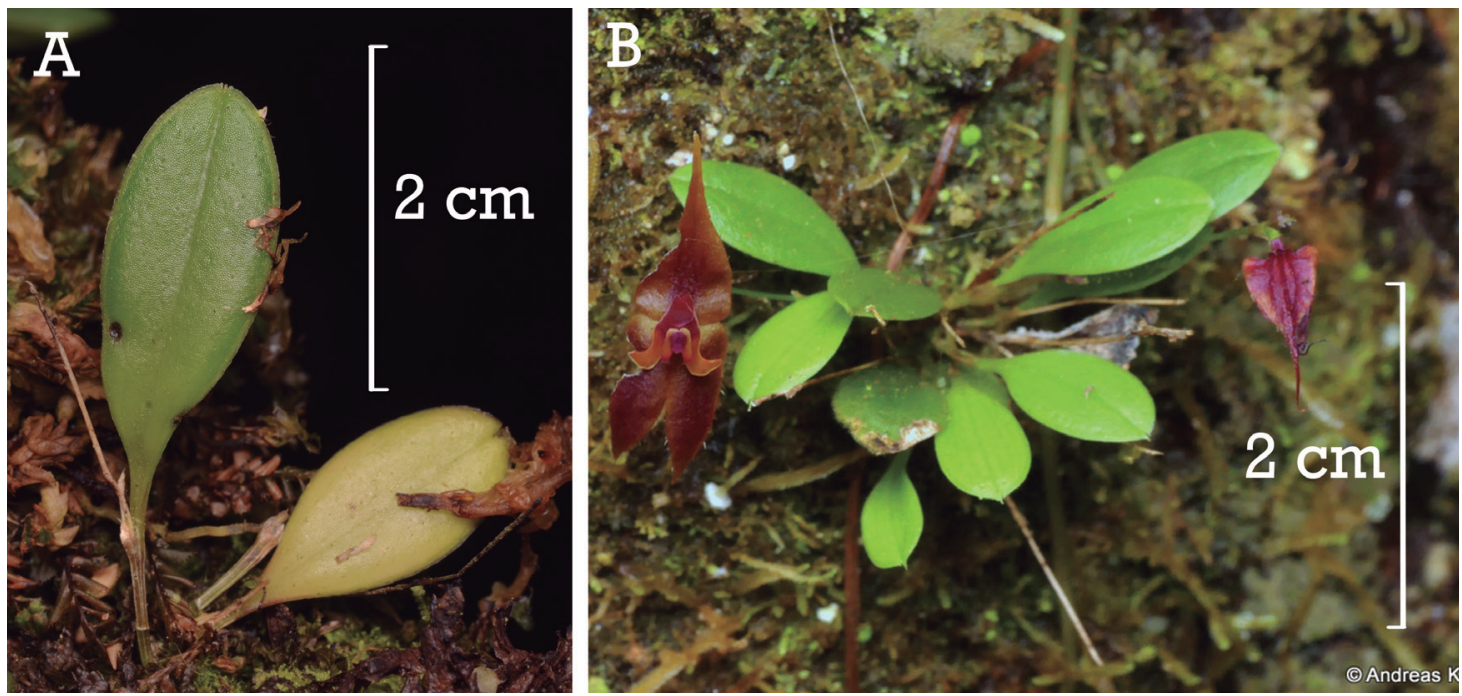

FiguRe 2. Plants of L. vere-aurum and L. brenneri Luer. A. Plant and leaves of L. vere-aurum in situ. B. Plant and leaves of

L. brenneri in situ. Photos in situ by Javier Donoso (A) and Andreas Kay† (B).

TYPE: Ecuador. Zamora-Chinchipe: Tundayme vía al Quimi, 1418 m, 03³4’32.8” S, 78 25'10.7” W, 13 March 2019. J. Donoso 310 (holotype: QCNE).

Diagnosis: Species similar to Lepanthes brenneri Luer from which it differs in the bigger plants (leaves of $10-17 \mathrm{~mm}$ long vs. 6-8 $\mathrm{mm}$ long in L. brenneri), the obovate leaves with obtuse apex (vs. elliptical with subacute apex in L. brenneri), the longer inflorescences in $L$. vere-aurum (up to $12 \mathrm{~cm}$ long vs. $1.3 \mathrm{~cm}$ long in L. brenneri), the obovate, concave and long-acuminate dorsal sepal in L. vere-aurum ( $v$ s. the flat, triangularovate, acuminate dorsal sepal in L. brenneri), and the oblong and concave appendix in $L$. vere-aurum with a pubescent crest underneath and a long, pubescent apex (vs. the triangular appendix with a ciliate apex in $L$. brenneri).

Plant small, up to $22 \mathrm{~mm}$ long, epiphytic, caespitose. Roots slender, $0.8 \mathrm{~mm}$ in diameter. Ramicauls abbreviated, 2-6 mm long, enclosed by 3 ribbed, lepanthiform sheaths. Leaf erect, coriaceous, obovate, obtuse, apiculate, 10-17 mm long, 4.0-6.5 $\mathrm{mm}$ wide, the base cuneate into a petiole $1-5 \mathrm{~mm}$ long. Inflorescence a progressively lengthening, flexible, loose, lightly flexuous raceme up to $12 \mathrm{~cm}$ long, peduncle 10-30 mm long, successively flowered with only one flower open at a time. Dorsal sepal yellow suffused with red except for the apex, concave, the blade glabrous, the markings slightly erose, obovate, with an acute, long-acuminate apex, 8-10 mm long, including a $3 \mathrm{~mm}$ long tail, $4-5 \mathrm{~mm}$ wide, three-veined, with three spiculate carinae at the abaxial side. Lateral sepals yellow suffused with red towards the fusion of both sepals, the blades glabrous, margins sparsely spiculate, obovate, oblique with an acute, acuminate apex, 7-9 mm long (including the tail), 3-4 mm wide, one-veined, with one spiculate carina at the abaxial side. Petals yellow, suffused with pink, slightly velvety, transversely bilobed, with an acute apex $2.5 \mathrm{~mm}$ wide, $0.5 \mathrm{~mm}$ long, the upper lobe oblong, obtuse, the lower lobe uncinate to broadly uncinate, apex acute. Lip yellow suffused with pink at the base of the blades, minutely pubescent, bilaminate, the blades oblong with the ends rounded, the apices long ciliate, $1.5 \mathrm{~mm}$ wide, $0.75 \mathrm{~mm}$ long, the connectives broadly cuneate, $0.4 \mathrm{~mm}$ long, the body narrow, connate to the base of the column, the appendix oblong, concave, with a pubescent crest below and along the entire length, the apex long with two glabrous, oblong calli at each side of the pubescent terminal part, $0.3 \mathrm{~mm}$ long. Column $0.75 \mathrm{~mm}$ long, the anther apical, the stigma transverse, apical.

PARATyPe: Ecuador. Zamora-Chinchipe: El Quimi, 900 m, 03³3’58” S, 78²8'56” W, September 42019 , Ecuador, Tundayme, J. Donoso 311 (QCNE). 


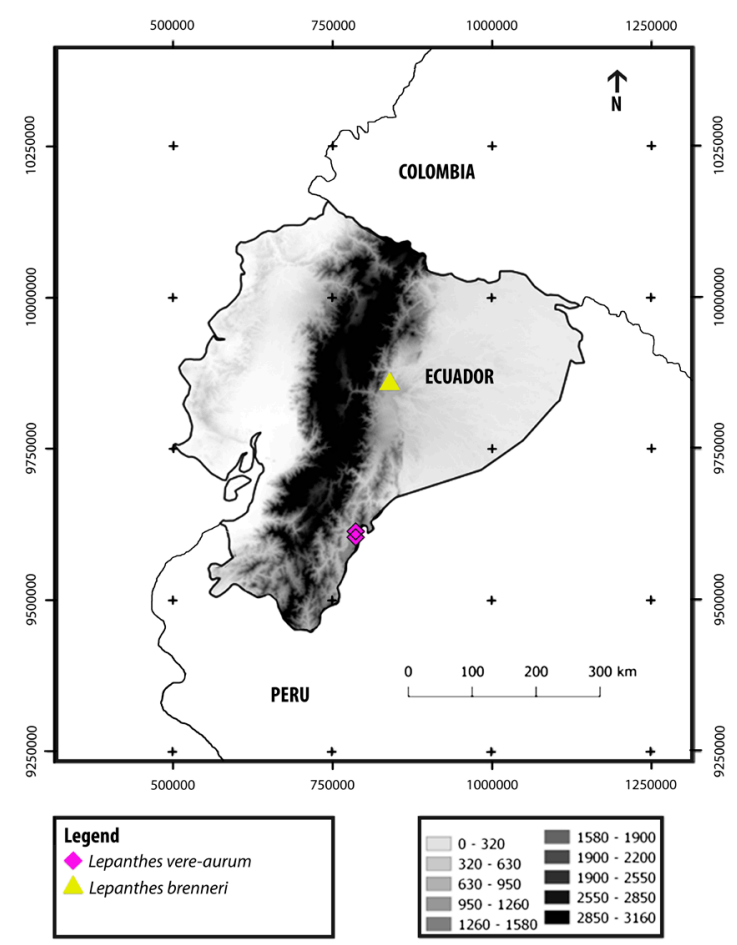

FIGURE 3. Map showing localities of Lepanthes vere-aurum and the type locality of L. brenneri. Map created by Marco Monteros.

Eтymology: From the Latin vere, truly, and aurum, gold, so named named to raise awareness of the intrinsic value of wild and endangered orchids (even scarcer than the precious metal) under threat of mining activities, and due to the golden color of the flowers.

HABITAT AND ECOLOGY: Lepanthes vere-aurum has been found growing as an epiphyte in the cloud forests of southern Ecuador. Two populations of this species grow nearby (between $900-1418 \mathrm{~m}$ in elevation), where no more than five plants were witnessed growing between the two sites. The holotype of the new species was collected at $1418 \mathrm{~m}$ in elevation, growing in a cloud forest of the Cordillera del Condor. This plant was found growing as an epiphyte on a fallen branch of a tree species belonging to the genus Guatteria (Annonaceae). Other orchid species belonging to the Pleurothallidinae, such as Lepanthopsis sp., Specklinia (ex Acostea) and Trichosalpinx sp., were growing sympatrically on the same branch. When collected, the plant of $L$. vereaurum was in flower (Fig. 3).
Phenology: This species has been observed blooming in its habitat in different months (May, June and December). In culture, a single plant shows long and consecutively flowered inflorescences which lasts for several months.

Lepanthes vere-aurum is similar to L. brenneri in the small plants (less than $5 \mathrm{~cm}$ long) with very short ramicauls, the big flowers when compared to the leaves, and the inflorescences that exceed the length of the leaves. Lepanthes brenneri differs from $L$. vere-aurum in the lower lobes of the petals which are uncinate and with a shape unique for the genus (Fig. 4). Furthermore, L. vere-aurum has bigger plants and obovate leaves with obtuse apex, different from the smaller plants of L. brenneri, with the leaves elliptic, subacute. The inflorescences in L. vere-aurum are much longer than in L. brenneri and the flowers have wider sepals, with the lateral sepals conspicuously oblique. Also, the shape of the appendix is different in both species: with a concave oblong appendix in $L$. vere-aurum and a smaller, triangular appendix in L. brenneri (Fig. 2, 4).

Lepanthes brenneri grows far north of where $L$. vere-aurum has been found. Since the original discovery of $L$. brenneri, few new encounters with this species have happened. The latest known encounter was made by the explorer and photographer Andreas Kay (Fig. 2-3) not far from Puyo in lower elevation slopes of the eastern Andes of Ecuador and at the base of the independent range of Cordillera Abitagua (both sites in northeast Ecuador). A couple of plants were photographed by Kay not distant from where the holotype was discovered in 1976. Lepanthes vereaurum grows farther south at the western slopes of the Cordillera del Condor, an independent mountain range from the eastern Andes of Ecuador.

Conservation status: Considering the two plants used in this study and others witnessed and photographed were growing within active mining sites, this species is considered to run a high risk of extinction due to the destructive nature of forests characteristic from mining activities in Ecuador. The forests where the holotype and paratype came from have disappeared already. There are no other known living plants or populations of the new species in the wild which does necessarily mean it is extinct. We recommend including it under the IUCN category of Critically Endangered (Fig. 3). 


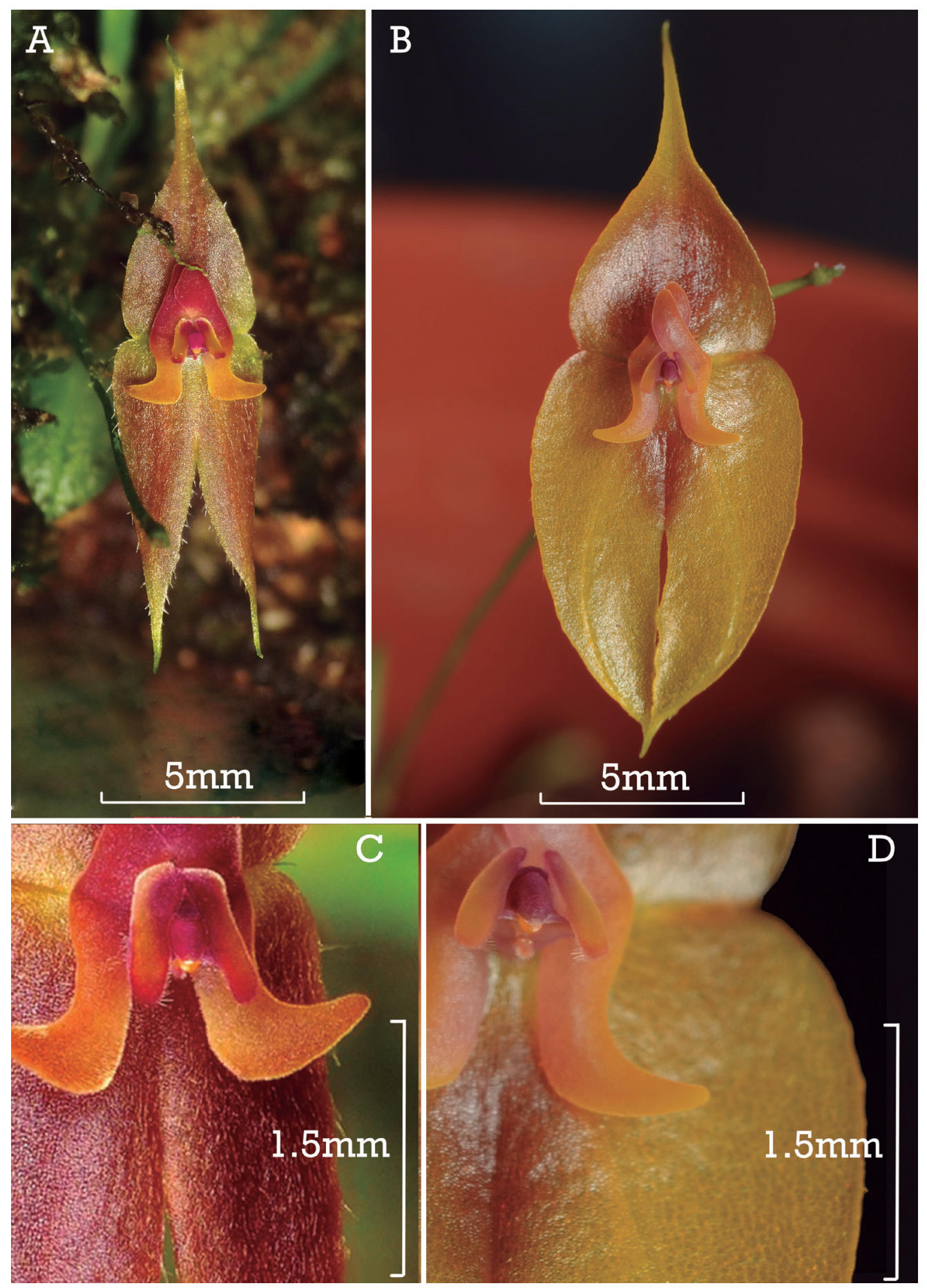

Figure 4. Comparison of Lepanthes vere-aurum Donoso \& Baquero and L. brenneri Luer. A. Flower of L. brenneri in situ. B. Flower of $L$. vere-aurum in studio (from JD 311 paratype, QCNE). C. Lower petal lobe and lateral sepal comparison of L. brenneri. D. Lower petal lobe and lateral sepal comparison of L. vere-aurum. Photos by Andreas Kay $\dagger$ (A, C) and Luis Baquero (B, D). 
ACKNOWLEDGEMENTS. The authors wish to acknowledge and dedicate this paper to Andreas Kay, who recently passed away, and is the author of the photos of Lepanthes brenneri used in this paper and of much other biodiversity found in Ecuador. We thank Marco Monteros for his help in this paper. We acknowledge Universidad de Las Americas
(UDLA) for funding research on orchids in Ecuador. The Ministerio del Ambiente del Ecuador is acknowledged for issuing the Environmental Research Permit No. 008-2016-IC-FLO-DNB/MA. Finally, we are grateful to the Editor and the anonymous reviewers for suggestions on the manuscript.

\section{LITERATURE CITED}

Baquero, L. E. (2018). A new species of Lepanthes (Orchidaceae: Pleurothallidinae) from northwestern Ecuador. Phytotaxa, 343(1), 75-81.

Baquero, L. E., Jaramillo-Vivanco, T. \& Verkovitch, D. G. (2019). A new and showy species of Lepanthes (Orchidaceae: Pleurothallidinae), from north-western Ecuador. Lankesteriana, 19(2), 99-105.

Baquero, L. E., Moreno, J. S. \& Iturralde, G. A. (2018). The four-footed Lepanthes (Pleurothallidinae), a new species from northwestern Ecuador. Lankesteriana, (18)3, 183-188.

Blanco, M. A \& Barboza, G (2005). Pseudocopulatory pollination in Lepanthes (Orchidaceae: Pleurothallidinae) by fungus gnats. Annals of Botany, 95(5), 764-772.

Endara, L. \& Jost, L. (2012). Orchidaceae. En: S. León Yánez, R. Valencia, N. Pitman, L. Endara, C. Ulloa \& H. Navarrete (eds.), Libro rojo de las plantas endémicas del Ecuador, Segunda Edición (pp. 441-444, 522). Quito. Ecuador: Herbario QCA, Pontificia Universidad Católica del Ecuador.

Jiménez V., M. M. \& Jiménez L., M. M. (2014). Orquídeas de Zamora Chinchipe, Tomo I: Epidendroidae (pp. 24-26). Quito. Ecuador: Casa de la Cultura Ecuatoriana Benjamín Carrión.

Karremans, A. P. (2016). Genera Pleurothallidinarum: an updated phylogenetic overview of Pleurothallidinae. Lankesteriana, 16(2), 219-241.

Luer, C. A. (1996). Icones Pleurothallidinarum. XIV. Systematics of Draconanthes, Lepanthes subgenus Marsipanthes and subgenus Lepanthes of Ecuador. Monographs in Systematic Botany from the Missouri Botanical Garden, 61, 1-255.

Thoerle, L. \& Hirtz, A. C. 2015. Three new Lepanthes species (Pleurothallidinae, Orchidaceae) from Ecuador. Phytotaxa 201(1): 50-62.

Tobar, T., López, M. F., Muñóz-Upegui, D \& Richter, F. (2018). Two new species of Lepanthes (Pleurothallidinae; Orchidaceae) from Andean forest remnant in Ibarra, Ecuador. Phytotaxa, 375(3), 221-228.

Zambrano, J. \& Solano, R. G. (2019). Two new Pleurothallidinae (Orchidaceae) from Southwestern Ecuador: Acianthera pustulata and Lepanthes marioi. Phytotaxa, 422(3), 255-272. 